\title{
Wartości moralne zawarte w Kodeksie Etyki Zawodowej Pielęgniarki i Położnej Rzeczpospolitej Polskiej [KEZPiP RP] w świetle medycznych modeli komunikacyjnych
}

\author{
Moral values contained in the code of professional ethics of nurses and midwives in Poland
} in the light of medical communication models

\section{Marta Szabat}

Zakład Filozofii i Bioetyki, Wydział Nauk o Zdrowiu, Uniwersytet Jagielloński, Collegium Medicum

\author{
AUTOR DO KORESPONDENCJ: \\ Marta Szabat \\ Zakład Filozofii i Bioetyki UJCM \\ ul. Michałowskiego 12, 31-126 Kraków \\ e-mail: marta.szabat@uj.edu.pl
} modeli komunikacyjnych

Wprowadzenie. Praktyczna realizacja wartości moralnych zawartych w Kodeksie Etyki Zawodowej Pielęgniarki i Położnej RP [chodzi m.in. o szacunek dla pacjenta, dbanie o jego godność, intymność, rzetelne wypełnianie obowiązków zawodowych itp.] jest nieodłącznym elementem praktyki zawodowej i wiąże się z wyborem określonego, indywidualnie dopasowanego, modelu komunikacji z pacjentami. Komunikacja zaś istotnie wpływa na jakość opieki pielęgniarskiej.

Cel pracy. Ocena możliwości realizacji wartości moralnych zawartych w kodeksie etyki zawodowej w ramach poszczególnych modeli komunikacyjnych [pod uwagę wzięte zostaną następujące modele: biomedyczny, holistyczny, humanistyczny].

Materiał i metodyka. Metoda hermeneutyczna, zgodnie z którą poprzez analizę porównawczą treści KEZPiP RP z założeniami określonych modeli komunikacyjnych potwierdza przekonanie, że to na relacji z drugim człowiekiem potrzebującym i chorym pielęgniarstwo powinno budować inne kompetencje zawodowe oparte na specjalistycznej wiedzy medycznej.

Wyniki. Model biomedyczny znajduje bardzo słabe odzwierciedlenie w kodeksie etyki zawodowej. Najlepszym wyrazem wartości moralnych są modele: humanistyczny i holistyczny. W modelu humanistycznym możliwe jest zaangażowanie w relację z pacjentem, przyjęcie postawy empatycznej, wprowadzenie do wywiadu elementów rozmowy - odniesienie do Części Szczegółowej z Kodeksu, I. Pielęgniarka/położna a pacjent, pkt 1-2, 7-8. W modelu holistycznym personel pielęgniarski i pacjent są dla siebie nawzajem partnerami a ich relacje opierają się na odpowiedzialności, dojrzałości, poszanowaniu godności i autonomii. Wymienionym założeniom odpowiada pkt 3-6, 9 z Części szczegółowej, I. Pielęgniarka/Położna a pacjent.

Wnioski. Wartości moralne zawarte w treści Kodeksu Etyki Zawodowej Pielęgniarki i Położnej RP mogą być realizowane najpełniej w modelu humanistycznym i holistycznym.

Introduction. The practical realization of moral values contained in the code of professional ethics for nursing (such as: respect for the patient, care for their dignity, intimacy, reliable completion of professional duties) is an integral part of nurses' professional practice and involves picking a specific, individually tailored model of communicating with patients. Appropriate communication significantly affects the quality of nursing care.

Aim. Assessment of the feasibility of moral values contained in the code of professional ethics in the context of individual models of communication (taking into account the following models: biomedical, holistic, humanistic).

Material and Methodology. Hermeneutical method, whereby through a comparative analysis of the content of the code of professional ethics for nurses and midwives in Poland with the assumptions of specific communication models confirms the theory that a relationship between nursing staff and patients may become a basis for building nursing professional competence based on medical expertise. 
Results. The biomedical model is rarely referred to in the code of professional ethics. The best expressions of moral values are the humanistic and holistic models. In the humanistic model, nursing staff can have a relationship with a patient and can demonstrate an empathetic attitude as well as introduce elements of conversation to the interview - a reference to the Special Parts of the Code, I. Nurse/midwife and patient, paragraphs 1-2,7-8. In the holistic model, nursing staff and the patient are one another's partners and their relationships are based on responsibility, maturity, respect for dignity and autonomy. This assumption corresponds to the point 3-6, 9 of the Special Parts of the Code, I. Nurse/midwife and patient.

Conclusions. The moral values contained in the text of the code of professional ethics for nurses and midwives in Poland can be realized most fully in humanistic and holistic models.

Key words:

ethics, communication, responsibility

\section{WPROWADZENIE}

Rozważania na temat wartości moralnych zawartych w Kodeksie Etyki Zawodowej Pielęgniarki i Położnej RP [1] [dalej: KEZPiP RP] warto zacząć od doprecyzowania zarówno pojęcia wartości moralnej, jak i istoty oraz celu kodeksu etyki zawodowej. W niniejszym artykule wartość moralna jest rozumiana jako kategoria aksjologiczna oznaczająca rzeczy dobre lub złe ze względu na cel i/lub rezultat jaki one wywołują [2]. Może być ona rozpatrywana $\mathrm{z}$ dwóch zasadniczych punktów widzenia - normatywnego i konsekwencjalistycznego [3]. Należy także doprecyzować, że od lat 80 - tych w zakresie etyki pielęgniarskiej powstało i nadal powstają opracowania koncentrujące się, z jednej strony, na normatywnym aspekcie etyki pielęgniarskiej a $\mathrm{z}$ drugiej na badaniach empirycznych [4]. W niniejszym artykule decyduję się na odróżnienie normatywnych wartości moralnych od tych ocenianych post factum, jako konsekwencji działań, przy czym, analizując KEZPiP RP przyjmuję perspektywę normatywną ze względu na charakter samego kodeksu. Przeciwstawienie więc normatywizmu konsekwencjalizmowi, a nie empirii, wiąże się z przyjęciem wąskiej perspektywy badawczej ograniczonej do przesłanek zawartych w KEZPiP RP.

$\mathrm{W}$ artykule koncentruję się na normatywnym wymiarze wartości moralnych zawartych w KEZPiP RP, na który składają się pozytywne wartości aksjologiczne potrzebne w praktyce zawodowej oraz określone cechy charakteru (zalety, cnoty) pozwalające realizować zasadniczy cel pielęgniarstwa jakim jest pielęgnowanie i opieka nad chorym pacjentem. W tym kontekście wymagane cechy charakteru podporządkowane będą głównemu celowi, czyli dobru pacjenta [5]. Normatywny charakter wartości moralnych to, w wypadku pielęgniarstwa, zbiór nakazów i zakazów moralnych pozwalających wypracować określony wzorzec osobowy $\mathrm{w}$ pracy $\mathrm{z}$ pacjentem oraz właściwy standard opieki pielęgniarskiej.

Teoretycznym wyrazem pozytywnych norm moralnych w pielęgniarstwie jest KEZPiP RP. Nie może on być traktowany jako dokument prawny. Jest to zbiór etycznych zasad postępowania składających się na powinności zawodowe w praktyce pielęgniarskiej. To wyraz zasad składających się na etykę zawodową.

Przedmiotem analizy jest KEZPiP RP uchwalony przez Krajowy Zjazd Pielęgniarek i Położnych 9.12.2003 roku. Zastąpił on kodeks etyki zawodowej z 1995 roku, którego wnikliwa i dokładna analiza znajduje się w pracy Anny Nawrockiej Etos w zawodach medycznych [5]. W wymienionej pracy został nakreślony również rys historyczny pielęgniarskiego etosu, począwszy od starożytności aż po ukształtowanie się pielęgniarstwa jako zawodu.

W KEZPiP RP zawarte zostały elementy trzech podstawowych modeli komunikacyjnych przyjętych w medycynie - biomedycznego, holistycznego oraz humanistycznego [6-10]. Już na początku należy zaznaczyć, że termin „model” odnosi się do określonej struktury teoretycznej i wzoru postępowania [8]. W pielęgniarstwie modele i wzorce są potrzebne, jednakże podstawową sferą działania jest praktyka zawodowa. To w niej ujawniają się określone wzorce zachowań, profesjonalizm lub jego brak. To również w praktyce wyraźnie zauważalna jest umowność wymienionych trzech modeli komunikacyjnych, które zazwyczaj zazębiają się.

W opracowaniach na temat etosu zawodowego pielęgniarstwa na pierwszy plan wysunięta zostaje, autonomiczna oraz oparta na współpracy, pielęgnacja i opieka $[4,5]$. Stąd, pielęgniarstwo ma wymiar przede wszystkim humanistyczny, to znaczy nakierowany na człowieka chorego, potrzebującego. Ze względu na to, w zakresie edukacyjnym, na studiach pielęgniarskich osoby kształci się holistycznie - nie tylko w zakresie medycyny, lecz także psychologii, filozofii i etyki zawodowej, socjologii, antropologii, wiedzy o kulturze. Oprócz specjalistycznej wiedzy medycznej, opieka nad pacjentem wymaga dostosowania tejże do jego preferencji psychiczno-intelektualno-duchowych, co stanowi bardzo wymagający aspekt praktyki zawodowej [5].

KEZPiP RP to dokument wyrastający z praktyki, teoretycznie porządkujący zasady etyki zawodowej. Widoczne są w nim elementy wszystkich trzech modeli komunikacyjnych, nazywanych także modelami zdrowia [8], z przewagą holizmu i humanizmu.

\section{CEL PRACY}

Celem niniejszego artykułu jest wskazanie tych aspektów KEZPiP RP, w których zarówno model holistyczny oraz humanistyczny, jak i biomedyczny znajdują odzwierciedlenie. W pielęgniarstwie podstawą profesjonalizmu jest i musi być dobra relacja $\mathrm{z}$ drugim człowiekiem potrzebującym opieki. W artykule będę bronić przekonania o konieczności uwypuklenia faktu, że to na relacji z drugim człowiekiem potrzebującym i chorym pielęgniarstwo powinno budować inne kompetencje zawodowe oparte na specjalistycznej wiedzy medycznej. Potwierdzenie tego przekonania zawarte jest w KEZPiP RP. 


\section{MATERIAŁ I METODYKA}

Rozważania w niniejszym artykule zostały oparte na metodzie hermeneutycznej. Zgodnie z nią poprzez analizę porównawczą treści KEZPiP RP z założeniami określonych modeli komunikacyjnych potwierdzam przekonanie, że to na relacji $z$ drugim człowiekiem potrzebującym i chorym pielęgniarstwo powinno budować inne kompetencje zawodowe oparte na specjalistycznej wiedzy medycznej.

\section{OMÓWIENIE}

W Przyrzeczeniu KEZPiP RP, jako pierwsze, zawarte zostało stwierdzenie następującej treści: Sprawować profesjonalna opieke nad życiem i zdrowiem ludzkim. Połączenie słów takich jak profesjonalizm i opieka w jeden termin: profesjonalna opieka nie tylko natychmiast odniesione zostaje do praktyki zawodowej, lecz także nadaje specyficzny wyraz profesjonalnemu podejściu do pacjenta polegającemu na opiece nad nim. Profesjonalna opieka nie będzie więc dotyczyła wyłącznie technicznego, biomedycznego podejścia do pacjenta, na które składają się takie elementy jak: wiedza, ingerencja diagnostyczno-terapeutyczna, działania manualne i instrumentalne. Profesjonalna opieka będzie dotyczyła przede wszystkim, o czym jest mowa w pkt 2 Przyrzeczenia, współuczestniczenia w procesie terapeutycznym, niesienia pomocy każdemu człowiekowi (pkt 3 Przyrzeczenia) oraz okazywania pacjentom należnego szacunku, nie nadużywania ich zaufania (pkt 4 Przyrzeczenia). Powyższe punkty zawarte w Przyrzeczeniu KEZPiP RP zarysowują rzeczywisty kontekst pielęgniarskich działań zawodowych. Pacjent to nie przedmio działań terapeutycznych. Przeciwnie, pacjent to człowiek chory, potrzebujący pomocy. To podmiot działań terapeutycznych, z którym można współuczestniczyć w leczeniu. Współodczuwanie jako jedna $\mathrm{z}$ cech tak zwanej inteligencji emocjonalnej to podstawa profesjonalnej opieki. To również cecha obu modeli - holistycznego i humanistycznego opisujących te cechy u osób zajmujących się chorymi, które pozwalają przekroczyć ów poznawczo-behawioralny schemat podmiotowo-przedmiotowy, w którym za podmiot może być uznana wyłącznie osoba poznająca, a więc, w tym wypadku, członek pielęgniarskiego personelu medycznego, natomiast drugiej stronie przypisany zostaje status przedmiotu poznania. Nie przypadkiem w początkowych punktach Przyrzeczenia jest mowa o wartościach humanistycznych związanych $\mathrm{z}$ budowaniem relacji $\mathrm{z}$ pacjentem. Również w Części Szczegółowej zatytułowanej Pielęniarka/położna a pacjent jako pierwsza wymieniona została zasada udzielania wszystkim pacjentom troskliwej opieki zgodnej z obowiązującymi standardami. Natomiast dopiero w pkt 6 Przyrzeczenia jest mowa o rozwijaniu innych kompetencji zawodowych, w tym wdrażania do praktyki nowych zdobyczy nauk medycznych. Mazurek J. stwierdza:

Przyjęcie postawy humanistycznej wiąże się z określonym podejściem do pacjenta i do prowadzonej terapii. Skutkuje ono tym, że pacjent czuje koło siebie żywego człowieka, a nie „naukowca”. Pacjent czuje, że sam też jest traktowany jak żywy i prawdziwy człowiek - jako osoba, a nie przedmiot manipulacji badawczych i terapeutycznych [10].

W tym miejscu warto także podkreślić, że współodczuwanie i empatia nie mogą być jedynie rodzajem emocji, lecz muszą wynikać z decyzji podjęcia właściwej opieki pielęgniarskiej. W artykule Care as a Moral Attitude In Nursing [Troska/opieka jako postawa moralna $w$ pielęgniarstwie] Gastmans C. podkreśla, że troska i opieka nie mogą być zredukowane ani do wyłącznie emocjonalnego podejścia do pacjenta, ani do instrumentalnego i technicznego traktowania opieki nad chorym. Stąd opieka (care) jako podejście do pacjenta jest, z jednej strony, zawsze konkretna, odniesiona do określonej sytuacji. Z drugiej zaś strony, mając na uwadze „wzloty” i „upadki” pacjenta, w opiece celem nadrzędnym jest jak najlepsza jakość życia chorego. Gastmans podkreśla wagę możliwości rozwoju personalnego zarówno pracowników personelu pielęgniarskiego, jak i pacjentów. W specyficznej sytuacji choroby i we wzajemnej relacji można nie tylko się wiele nauczyć, wzbogacając doświadczenie zawodowe, lecz także wyciągnąć wnioski na temat przyszłej opieki pielęgniarskiej. Wiedza, komunikacja oraz interpretacja jako umiejętność właściwego odczytywania potrzeb pacjentów to istotne cechy właściwej opieki medycznej. Opieka pielęgniarska jako postawa moralna byłaby zatem nie tyle umiejętnością właściwego reagowania w określonych sytuacjach, ile umiejętnością właściwego bycia w kontakcie z pacjentami [11]. W tym kontekście, doświadczenie zawodowe może być rozumiane jako dynamiczny proces uczenia się zarówno na płaszczyźnie osobistej dojrzałości emocjonalnej, jak i nabywania nowych, przydatnych kompetencji zawodowych nie tylko w celu zdobycia wyłącznie odpowiednich kwalifikacji, lecz także po to, by ujawniać istotę i sens opieki pielęgniarskiej jako sposobu/stylu życia.

W holistycznym modelu zdrowia proponuje się personelowi medycznemu rozwijanie takich wartości moralnych jak odpowiedzialność za pacjenta, szacunek dla jego autonomii, poszanowanie jego godności. Pacjent to człowiek w wymiarze psychicznym, cielesnym oraz duchowym potrzebujący troski i opieki z powodu choroby. Nie może on być traktowany jako klient, ponieważ nie przychodzi po pomoc z własnej woli i choroba nie jest jego wyborem. Przeciwnie, zmuszony dolegliwościami zgłasza się po pomoc, licząc na odpowiedzialne podejście ze strony personelu medycznego. Stąd tak ważne jest dostrzeganie roli odpowiedzialności w praktyce pielęgniarskiej. W 7 pkt Przyrzeczenia zapisane zostało: Rzetelnie wypetniać obowiazki wynikajace $z$ pracy $w$ tym zawodzie. Rzetelne wypetnianie obowiązów oznacza indywidualne podejście do obowiązujących standardów dobrej praktyki klinicznej, co w praktyce składa się na odpowiedzialność. Istotne jest także ujmowanie odpowiedzialności nie tylko w kategoriach normatywnie obowiązujących i niezmiennych, lecz także podejście do odpowiedzialności zawodowej jako do dynamicznie rozwijającej się osobistej odpowiedzi na wyzwania praktyki zawodowej. Postawa odpowiedzialności to nieustanne, dynamiczne bycie w relacji z osobami powierzonymi opiece medycznej. Wydaje się 
to warunkiem rzetelności, która nie może być rozumiana jedynie jako techniczne wdrażanie medycznych procedur. W pkt 5 w Części Ogólnej stoi napisane: Pielęgniarkal położna posiadajaca pełne uprawnienia zawodowe ponosi osobista odpowiedzialność za swoje działania. Odpowiedzialność to nie tylko wykonywanie określonych i ustalonych obowiązków. To przede wszystkim osobiste ponoszenie konsekwencji własnych działań w relacji z innymi.

Gastmans podkreśla systemowy kontekst odpowiedzialności, w którym personel pielęgniarski ponosi odpowiedzialność oraz poczuwa się do niej w zakresie czynności dotyczących specyfiki wykonywanego zawodu. Jego zdaniem opieka pielęgniarska jako postawa moralna zawsze musi mieć na uwadze możliwy do rozpoznania kontekst systemu ochrony zdrowia, gdzie prowadzona jest opieka. W pielęgniarstwie nie można przyzwalać na nieprawidłowości, nawet, jeżeli występują one poza zakresem obowiązków pielęgniarskich, po stronie innych specjalistów prowadzących terapię, czyli lekarzy lub innego personelu pomocniczego. Wówczas odpowiedzialność jako postawa ma szansę przełożyć się na osobiste życie i stać się integralną częścią osobowości oraz charakteru danej osoby [11].

Część Szczegółowa, Pielęgniarka/położna a pacjent, oprócz standardowych zaleceń takich jak udzielanie pacjentowi pierwszej pomocy w stanach zagrożenia zdrowia i życia, zachowywanie tajemnicy zawodowej, edukacja rodziny pacjenta $\mathrm{w}$ zakresie czynności wobec niego podejmowanych, zapewnienie choremu dostępu do opieki duchowej, zapewnienie właściwej opieki paliatywnej (w razie potrzeby) czy udzielanie mu rzetelnej i zrozumiałej informacji w zakresie pielęgnacji, zawiera również zalecenia aksjologiczne na temat relacji z pacjentami. Są one wyrazem holistycznego i humanistycznego podejścia do pacjenta. W ramach odpowiedzialnej realizacji pielęgniarskiej praktyki zawodowej pacjentowi powinna być okazywana życzliwość, wyrozumiałość, cierpliwość oraz tworzona atmosfera wzajemnego zaufania i zrozumienia (pkt 2), obowiązuje respektowanie praw pacjenta do intymności i godności osobistej podczas udzielania świadczeń medycznych, poszanowanie jego decyzji co do zgody lub odmowy leczenia, w tym informacja o możliwych skutkach jego decyzji oraz podjęcie próby przekonania pacjenta, aby zmienił swoje zdanie, w przypadku gdy odmowa leczenia może zagrażać jego zdrowiu lub życiu (pkt 3). Personel pielęgniarski nie może także pobierać od pacjentów nieuzasadnionego wynagrodzenia czy też uzależniać od tego ostatniego podjęcia opieki medycznej (pkt 9), co stanowi podstawę nieuznawania pacjenta za klienta, lecz za chorego potrzebującego pomocy i mającego do niej konstytucyjne prawo.

W Części Szczegółowej w paragrafie II Pielęgniarkal położna a praktyka zawodowa i nauka zawartych zostało najwięcej biomedycznych aspektów praktyki pielęgniarskiej. To przede wszystkim część „techniczna”, w której nacisk położony został na systematyczne uaktualnianie wiedzy medycznej i kompetencji zawodowych, prowadzenie dokumentacji medycznej, działalność na rzecz promocji zdrowia oraz w organizacjach zawodowych krajowych i międzynarodowych. Ważnym aspektem pracy zawodowej jest prowadzenie badań naukowych. Perspektywą dla tych zaleceń jest, $\mathrm{z}$ jednej strony, dobro pacjenta a $\mathrm{z}$ drugiej zgodność pracy zawodowej z osobistymi i powszechnie przyjętymi wartościami moralnymi. Ów humanistyczny kontekst części II dotyczy przede wszystkim klauzuli sumienia [12], zgodnie z którą personel medyczny może odmówić wykonywania czynności niezgodnych z wewnętrznym systemem wartości (przy czym pacjentowi powinien zostać zapewniony dostęp do świadczeń zdrowotnych u innego specjalisty bądź w innej placówce), i błędów medycznych, o których wiadomość, po zauważeniu bądź po popełnieniu błędu, niezwłocznie powinna zostać przekazana osobom z zespołu terapeutycznego (pkt 8).

$\mathrm{Na}$ uwagę zasługuje wizerunkowy aspekt tej części, w którym podkreślona zostaje waga pielęgniarstwa jako zawodu zaufania publicznego. Takie sformułowania jak: przysparzanie prestiżu zawodowi (pkt 9), cenienie i szanowanie zawodu, ochrona godności zawodu (pkt 11), powstrzymywanie się od działania mogącego spowodować złą opinię o zawodzie (pkt 12), szacunek dla historii i tradycji zawodu oraz dbanie o jego pozytywny wizerunek (pkt 13) wskazują na permanentne odniesienie pielęgniarstwa do społeczeństwa, czyli do pacjentów. Celem wymienionych wyżej działań jest wzbudzenie zaufania i szacunku zarówno ze strony pacjentów, jak i w obrębie samego pielęgniarstwa czy innych zawodów medycznych.

Część szczegółowa, punkty III (Pielęgniarka/położna a samorząd pielęgniarek i położnych) i IV (Pielęgniarkal położna a współpracownicy) dotyczą zasadniczo zasad współpracy samorządowej oraz zawodowej. Na pierwszy plan wysunięte zostały takie humanistyczne wartości moralne jak: solidarność, wsparcie, przestrzeganie ustalonych zasad i uchwał, szacunek, lojalność, koleżeństwo, wzajemna pomoc, sprawiedliwość ( $w$ tym bezstronna krytyka współpracowników, skierowana w pierwszej kolejności do osoby zainteresowanej), uczciwość, odpowiedzialność i współodpowiedzialność, rzetelność, pracowitość, dokładność. Wszystkie wymienione wartości można uznać za relacyjne, to znaczy kształtujące określone zalety/cnoty zawodowe w celu poprawy jakości opieki pielęgniarskiej jako takiej. Dobro wspólne współpracowników i pacjentów wymaga pracy nad sobą oraz pracy w ramach zespołu terapeutycznego. Wiedza zaś i kompetencje zawodowe powinny opierać się na pracy nad charakterem oraz na kształtowaniu odpowiedniej postawy moralnej. Nie odwrotnie. Wiedza powinna osadzać się na wartościach, ponieważ tylko wówczas będzie możliwy, postulowany w KEZPiP RP szacunek zarówno dla historii zawodu, jak i dla samego zawodu jako takiego. Nawrocka A. w pracy Etos zawodowy w zawodach medycznych ujmuje powyższe przekonanie w następujący sposób:

Istotą pielęgniarstwa jest służenie innym, pielęgnowanie, opieka, wzajemne kontakty, wyjaśnianie, porozumiewanie się, obserwacja. Pielęgniarstwo obejmuje służenie ludziom w celu zapobiegania chorobom, a więc udzielanie pomocy chorym, cierpiącym ludziom i opiekowanie się ludźmi potrzebującymi opieki, opiekowanie się dziećmi, starszymi, bezdomnymi. Jest to nie tylko opieka fizyczna 
polegająca na zaspakajaniu podstawowych potrzeb człowieka, ale również psychiczna wyrażająca się w dodawaniu otuchy, podtrzymywaniu na duchu osób znajdujących się w stresie, depresji, umierających i cierpiących. Pielęgniarstwo wymaga określonych cech charakteru: dobroci, życzliwości, miłości do ludzi, cierpliwości, zrozumienia istoty swojego zawodu, określonych wartości i perfekcyjnego przygotowania zawodowego [5 (243-244)].

W zagadnieniu relacji ważną rolę odgrywa komunikacja werbalna i niewerbalna $\mathrm{z}$ pacjentem, co znajduje odzwierciedlenie w etycznych normach z KEZPiP RP. Ze względu także na specyfikę praktyki pielęgniarskiej model biomedyczny znajduje nikłe odzwierciedlenie w kodeksie. Na poziomie werbalnym kluczową rolę pełni funkcja informacyjna rozumiana bardzo szeroko, począwszy od bardziej osobistych, personalnych porad i rozmów, skończywszy na profesjonalnym wsparciu informacyjnym ściśle dotyczącym zaleconego leczenia.

Po wszystkim co do tej pory zostało napisane wydaje się, że najbardziej odpowiednim modelem etycznym, który pomógłby zrealizować wartości moralne zawarte w KEZPiP RP jest etyka charakteru, inaczej nazywana etyką cnót wywodząca się z myśli Arystotelesa. Cnota moralna (współcześnie rozumiana jako zaleta) to cecha charakteru wartościowa moralnie ze względu na obiektywne wartości, takie jak dobro społeczne, sprawiedliwość, nieszkodzenie itp. Cnoty moralne są także pożądane społecznie. W KEZPiP RP na uwagę zasługują wszystkie cnoty moralne wyżej wymienione. Wydaje się także, że nie sposób rozwijać cnót takich jak życzliwość, cierpliwość, sprawiedliwość czy solidarność bez samoobserwacji czy bez etycznej postawy uważności (the ethical attitude of attentiveness), na którą to cechę zwraca także uwagę Gastmans [4], określając ją jako niezbędną $\mathrm{w}$ interpretacji potrzeb pacjentów przez personel medyczny. Cnoty moralne wymieniane w Przyrzeczeniu oraz w kolejnych podpunktach Części Szczegółowej są, w ścisłym znaczeniu, relacyjnymi, czyli dążącymi do wypracowania najlepszego poziomu opieki pielęgniarskiej. Etyka cnót, opierająca się na filozoficznych założeniach Arystotelesa, ma pokazywać ludziom możliwość i sposób życia pozwalający im stać się szczęśliwymi. U podstawy jej założeń leży również teza, że nie można być szczęśliwym w pojedynkę (jak choćby w liberalizmie), lecz jedynie we wspólnocie. Stąd wszelkie cnoty moralne ukierunkowane są relacyjnie na innych ludzi, na stosunki z nimi, na wzajemne kooperowanie. W etyce tej wyartykułowane zostaje przekonanie, że, aby skutecznie „zmieniać świat”, trzeba zacząć od własnego nastawienia i od pracy nad swoim charakterem. Gdyby większość członków danej wspólnoty indywidualnie rozwijała w sobie odwagę, życzliwość, pracowitość itp., to jakość moralna wspólnoty jako całości podniosłaby się. Zasada „złotego środka”, umiaru jako wypośrodkowania pomiędzy skrajnościami może służyć wypracowywaniu zarówno motywacji do działania, jak i działania samego w sobie [13].

Dobrym przykładem powiązania teorii cnót $\mathrm{z}$ wartościami moralnymi z KEZPiP RP może być ostatni merytoryczny punkt Części Szczegółowej (V. Pielęgniarka/położna a zasady postępowania wobec społeczeństwa), gdzie, po raz kolejny, podkreślona została konieczność czynnej i aktywnej postawy wszystkich przedstawicieli tego zawodu wobec, z jednej strony, zła społecznego a z drugiej propagowania wiedzy na temat dobrych wzorców zdrowotnych. Edukacja i profilaktyka to współcześnie dwa zasadnicze cele wszystkich dziedzin medycyny praktycznej. W tym kontekście postawa odwagi i uczciwości istotnie dopełniałaby pielęgniarstwo jako zawód.

Gastmans umieszcza opiekę pielęgniarską na styku ludzkiej podatności na zranienie (vulnerability) i godności (dignity). Opieka pielęgniarska bazująca na: (a) określonym doświadczeniu życiowym (w tym kulturowym), (b) na interpretowaniu relacji $\mathrm{z}$ pacjentami pozwalającemu na właściwe odczytywanie ich potrzeb oraz (c) na normatywnych standardach musi uwzględniać sytuację chorego, jako słabszego i potrzebującego pomocy, przy jednoczesnym szacunku dla jego godności. Istotą opieki powinna być odpowiedź na krzywdę/chorobę pacjentów (responding to vulnerability). Owa odpowiedź ujawnia etyczny wymiar opieki pielęgniarskiej [4]. Na każdej z wymienionych trzech płaszczyzn mogą pojawić się trudności. Stąd, tak istotne jest wypracowywanie osobistych zalet $\mathrm{w}$ relacjach $\mathrm{z}$ pacjentami oraz współpracownikami, ponieważ pozwala to nie tylko uchronić pacjentów przed niepotrzebnym bólem i cierpieniem, lecz także może podnieść jakość pracy w samym zespole terapeutycznym.

\section{WNIOSKI}

W powyższej analizie zostało pokazane, że najlepszym wyrazem wartości moralnych KEZPiP RP są modele humanistyczny i holistyczny. Model biomedyczny znajduje bardzo słabe odzwierciedlenie w KEZPiP RP.

W modelu humanistycznym możliwe jest zaangażowanie w relację z pacjentem, przyjęcie postawy empatycznej, wprowadzenie do wywiadu elementów rozmowy. W modelu holistycznym personel pielęgniarski i pacjent są dla siebie nawzajem partnerami a ich relacje opierają się na odpowiedzialności, dojrzałości, poszanowaniu godności i autonomii.

Analizy pokazują także, że to odpowiednie cechy charakteru pozwalające na zapewnienie pacjentowi właściwej opieki pielęgniarskiej powinny stanowić podstawę specjalistycznej wiedzy medycznej. To w relacji z pacjentem dochodzi do ujawnienia prawdziwego celu i istoty pielęgniarstwa. W nabywaniu więc kompetencji zawodowych wiedza powinna być poprzedzana odpowiedzialną postawą moralną, co umożliwi pamiętanie o tym, że przeznaczeniem wiedzy i kompetencji zawodowych jest zawsze drugi człowiek - pacjent.

\section{PIŚMIENNICTWO}

1. http://www.nipip.pl/index.php/samorzad/informacje-0-samorzadzie/2135kodeks-etyki-zawodowej-pielegniarki-i-poloznej-rzeczypospolitej-polskiej (dostęp: 23.08.2015).

2. Gulla A. Creating Values in Life. Personal, Moral, Spiritual, Family and Social Values. Liberty Drive Bloomington. Indiana: Bloomington; 2010.

3. Hurley P. Consequentialising and Deontologising: Clogging the Consequentialist Vacuum, Oxford Studies in Normative Ethics. 2013; vol. 3: 123-153.

4. Gastmans Ch. Dignity-enhancing nursing care: A foundational ethical framework, Nursing Ethics. 2013; 20 (2): 141-149. 
5. Nawrocka A. Etos w zawodach medycznych. Kraków: Wydawnictwo WAM; 2008. s. 99$115,252,256,258-273$.

6. http://nipip.pl/index.php/uchwaly/krajowych-zjazdow/iv-krajowego-zjazdupielegniarek-i-poloznych/uchwaly/896-9-04-2003 (dostęp: 23.08.2015).

7. Ostrzyżek A, Marcinkowski JT. Biomedyczny versus holistyczny model zdrowia a teoria i praktyka kliniczna, Problemy Higieny i Epidemiologii. 2012; 93(4): 682-686.

8. Kowalski M, Gaweł A. Zdrowie-wartość-edukacja. Kraków: Oficyna Wydawnicza "Impuls"; 2006. s. 16-17.

9. http://www.who.int/topics/nursing/en/ [dostęp: 25.08.2015].

10. Mazurek J. Fizjoterapia holistyczna, czyli psycho-fizjo-terapia. Część III: Człowiek w fizjoterapii, czyli od modelu biomedycznego, przez humanistyczny, do holistycznego, Fizjoterapia. 2009; 17 (4): 90.

11. Gastmans Ch. Care as a Moral Attitude in Nursing, Nursing Ethics. 1999; 6 (3): 214-223.

12. http://www.ptb.org.pl/pdf/dobrowolska_cegielko_klauzula_1.pdf [dostęp: 25.08.2015]

13. Beauchamp TL, Childress JF. Zasady etyki medycznej, przeł. W. Jacórzyński, Warszawa: Książka i Wiedza, 1996. s. 72-80.
Praca przyjęta do druku: 31.08.2015

Praca zaakceptowana do druku: 30.11.2015 